Світлана Криштанович. Формування професійної компетентності майбутніх інженерів 3 механізації сільського господарства: концептуальний аспект

\title{
УДК 796.075 \\ ФОРМУВАННЯ ПРОФЕСІЙНОЇ КОМПЕТЕНТНОСТІ МАЙБУТНІХ СПОРТИВНИХ МЕНЕДЖЕРІВ: НАУКОВІ ПІДХОДИ
}

\author{
Криштанович Світлана, \\ кандидат наук з державного управління, \\ доиент кафедри економіки, менеджменту \\ та готельно-ресторанного бізнесу \\ Львівського держсавного університету фізичної культури
}

КЛЮЧОВІ

СЛОВА:

наукові підходи методологічні

підходи,

професійна

компетентність,

спортивний

менеджер, вищі

навчальні заклади,

технології.

\begin{abstract}
Реферат
Проведений нами аналіз наукових праць, присвячених формуванню професійної компетентності майбутніх менеджерів фізичної культури i спорту в умовах динамічних змін на ринку праці, свідчить, що ця проблема як в теоретичному, так і в методологічному аспектах, досліджена недостатньо. Зокрема, грунтовно не проаналізовані наукові підходи до реалізації завдань ефективної професійного підготовлення цих фахівців. Своєчасність і доцільність застосування методології у процесі формування професійної компетентності майбутніх менеджерів фізичної культури і спорту зумовлена необхідністю розв'язання певних протиріч, а саме, між: замовленням суспільства на компетентного спортивного менеджера та недостатніми можливостями вітчизняної освітньої системи в процесі їх підготовлення; існуючою уніфікованою системою підготовлення майбутніх фахівців для сфери фізичної культури і спорту та необхідністю впровадження інновацій у навчально-виховний процес вищої школи; усвідомленням студентами необхідності й значущості розвитку професійної компетентності та недостатнім досвідом i рівнем ii сформованості; необхідністю самовдосконалення та розвитку професійних знань, умінь i навиків викладачів в умовах швидкоплинного освітнього середовища та їхньою неспроможністю швидко й оперативно адаптуватися до цих умов. Усунення зазначених суперечностей вимагає переусвідомлення концептуальнометодологічних підходів до підготовки майбутніх менеджерів фізичної культури і спорту, формування у них професійної компетентності.

Систему методологічних підходів до формування професійної крмпетентності майбутніх спортивних менеджерів визначають системний, теоретико-пізнавальний, компетентнісний, діяльнісний, особистісно орієнтований, технологічний, інтегративний та інші підходи. Нами було розглянуто зміст і суть цих підходів. Це дало змогу встановити основні вимоги до формування професійної компетентності майбутніх менеджерів фізичної культури і спорту та розуміння побудови навчального процесу у вищій школі для підготовки даних фахівців.
\end{abstract}

Постановка проблеми. Методологічний аналіз основ формування професійної компетентності майбутніх менеджерів фізичної культури i спорту передбачає узагальнення філософських ідей, закономірностей i загальнонаукових теоретичних положень, які сприяють не лише уточненню суті та визначенню специфіки професійної компетентності цих спеціалістів, а й обгрунтуванню наукових підходів та їх реалізацію в освітній системі вищих навчальних закладів.

Аналіз останніх досліджень і публікацій. Систему методологічних підходів до формування професійної компетентності майбутніх спортивних менеджерів визначають системний, компетентнісний, діяльнісний, особистісно орієнтований, технологічний, інтегративний та інші підходи. Розгляду системного підходу значну увагу приділяли: В. Бушуєва, Т. Дмитренко, О. Кудрявцев, А. Кузнецова, Н. Олейник, С. Омаров, Н. Крилова; компетентнісний підхід досліджували: В. Байденко, Н. Бібік, 
Е. Зеєр, I. Зимняя, В. Луговий, О. Овчарук, О. Савченко, С. Сисоєва, Ю. Татур, А. Хуторський; діяльнісний застосовували: Б. Ананьєва, Г. Атанова, Л. Буєва, Л Виготський, П. Гальперін, В.Давидов, О. Леонтьєв, С. Рубінштейн, Д. Ельконін; особистісно орієнтований підхід висвітлений у працях I. Беха, I. Зязюна, О. Пєхоти, В. Рибалки, В. Сєрікова, І. Якиманської; зміст акмеологічного підходу до формування професійної компетентності майбутніх спеціалістів розкривають, зокрема, дослідження Ю. Драгнєва й Н. Сегеди; основні засади професійної акмеології (предмет, принципи та методи іiі реалізації) розглядали Н. Вишнякова, Ю. Курамшин, С. Пожарський; суть праксеології вивчали Б. Григор'єв, В. Чумакова та ін. Відтак, багато аспектів формування професійної компетентності майбутніх менеджерів фізичної культури і спорту залишилися поза увагою науковців і тому потребують більш детального висвітлення.

Метою статті $\epsilon$ розкриття змісту й суті наукових підходів, які сприятимуть формуванню професійної компетентності майбутніх спортивних менеджерів у вищих навчальних закладах України.

Виклад основного матеріалу. Визначаючи філософсько-методологічні основи формування професійної компетентності майбутніх спортивних менеджерів, що $\epsilon$ відображенням фундаментальних положень, теорій i принципів, наукових основ процесу пізнання даного виду професійної діяльності, потрібно враховувати, що в наукових колах використовують кілька рівнів методології. Традиційно виокремлюються філософський, загальнонауковий, конкретно-науковий (спеціальний) та конкретно-тематичний (спеціалізований) рівні методології. Н. Гузій визначає суть процесу формування професійної компетентності в теорії і практиці підготовки майбутнього фахівця через виокремлення загальнофілософського, загальнонаукового, конкретно наукового рівнів, а також методологічної рефлексії, де інтегруються всі джерела методологічного забезпечення. Інтегруючи наукові підходи до структурування методологічного аналізу процесу формування професійної компетентності майбутніх менеджерів фізичної культури і спорту важливо, щоб проводилися вони за такими рівнями: філософським, що дає змогу застосовувати вчення про науковий метод пізнання парадигм i філософських принципів для розуміння суті певної професійної діяльності; загальнонауковий, що відображає систему використання загальнонаукових методологічних підходів у процесі формування професійної компетентності менеджерів фізичної культури i спорту; практично-технологічний - 3 метою обгрунтування оптимальних та ефективних технологій формування професійної компетентності цих спеціалістів.

Розглянемо зміст і суть цих підходів. Значення системного підходу до професійного розвитку майбутнього фахівця фізичної культури i спорту в умовах сучасного освітнього простору полягає в тому, що він $є$ методологічною орієнтацією, де об'єкт пізнання розглядається як система. Особливо актуальною для розгляду проблеми професійного розвитку майбутнього фахівця фізичної культури і спорту, з погляду різних підходів у педагогіці, є робота С. Крупника [6] «Методологічні підходи до предмету педагогіки», в якій підходи в педагогіці розподіляються на дві групи. До першої автор відносить ті, що формуються за допомогою онтологічного подання положень із різних гуманітарних наук. Другу групу він визначає як ціннісну орієнтацію на особистість, суспільство, інформацію тощо. Таким чином, системний підхід дає змогу визначити систему діяльності, спрямовану на оволодіння майбутніми менеджерами фізичної культури i спорту професійних функціональних компетентностей, що уможливлюють забезпечення єдності змісту, форм, методів та умов формування професійної компетентності цих спеціалістів у процесі їхньої фахової підготовки.

В останні роки значна кількість дослідників і практиків освіти звертаються до теоретико-пізнавального (гносеологічного) niдxодy як інструменту пошуку науковопедагогічного знання та вдосконалення навчального процесу [5]. Використання гносеологічного підходу у формуванні професійної компетентності майбутніх спортивних менеджерів передбачає використання основних методів наукового 
Світлана Криштанович. Формування професійної компетентності майбутніх інженерів 3 механізації сільського господарства: концептуальний аспект

пізнання, зокрема, порівняння традиційного навчання та процесу використання інноваційних педагогічних технологій, встановлення закономірностей цього процесу, визначення особливостей і напрямів удосконалення професійної підготовки студентів для галузі фізичної культури i спорту у ВНЗ тощо. Варто зазначити, що при застосуванні теоретико-пізнавального підходу відкривається можливість для аналізу наявних професійних знань майбутніх менеджерів фізичної культури i спорту 3 урахуванням їхніх характеристик та визначення істотних зв’ язків між елементами набутого знання. Цей підхід, окрім відповіді на запитання, що саме здійснюється в процесі формування професійної компетентності спортивних менеджерів, сприяє розкриттю суті механізму його реалізаціі, тобто допомагає зрозуміти, як саме це робиться в навчальному процесі.

Методологічною основою сучасних досліджень із професійної освіти $\epsilon$ компетентнісний підхід, який у «Національному освітньому глосарії: вища освіта» обгрунтовано як «підхід до визначення результатів навчання, що базується на ї описі у термінах компетентностей». Зазначається також: «Компетентнісний підхід $є$ ключовим методологічним інструментом реалізації цілей Болонського процесу» [8, с. 31]. Компетентнісний підхід розкриває цілі, зміст і методологію професійної освіти. Професійна компетентність майбутніх менеджерів фізичної культури і спорту розглядається як цілісна характеристика індивіда, об'єднання знань, умінь i навичок, які продукують професійний інтелект, фахові позиції та індивідуально-психологічні особливостіцих фахівців.

До основних методологічних підходів підготовки майбутніх менеджерів фізичної культури i спорту належить діяльнісний. Значний інтерес при визначенні застосування діяльнісного підходу становить робота А. Ільїної [4]. Розглядаючи діяльнісний підхід у процесі формування пізнавальної самостійності студентів, дослідниця доводить, що в основі цього підходу лежить засвоєння особистістю спеціального досвіду, що формується в процесі їі власної діяльності. I якщо студент стає справжнім суб'єктом навчання й бере активну участь в навчальнопізнавальній та навчально-професійній діяльності, то цілі його діяльності стають реальним двигуном розвитку різних видів його професійної діяльності. Тому під діяльнісним підходом ми розуміємо такий спосіб організації навчально-пізнавальної діяльності майбутнього спортивного менеджера, при якому він активно буде брати участь у навчальному процесі 3 професійною перспективою на майбутнє.

У системі методологічних підходів до розв'язання всієї сукупності завдань формування професійної компетентності майбутніх менеджерів фізичної культури i спорту важливе значення має особистісно орієнтований підхід, який виконує функцію системоутворювального. Створення у ВН3 особистісно-розвивального середовища $\epsilon$ необхідною умовою успішної реалізації в ньому сучасних методів підготовки спортивних менеджерів. За визначенням I. Зимньої [3], особистісно-орієнтований підхід, з позиції тих, хто навчається, означає наявність актуальної ситуації інтерналізації нових форм, правил, способів і засобів соціально-професіонально-комунікативної діяльності, тобто розвиток не тільки професійної компетентності студента, але й особистості його в цілому. Це, на думку дослідниці, означає, що на основі «переходу зовнішнього у внутрішнє» в студента будуть цілеспрямовано й ефективно формуватися саморегуляція та самооцінювання. Це сприятиме вирішенню основного освітнього завдання: створення умов для розвитку гармонійної, морально досконалої, соціально активної (через активізацію внутрішніх резервів), професійно компетентної особистості, яка саморозвивається.

У підготовці майбутніх фахівців фізичної культури i спорту важливим $\epsilon$ методологія реалізації технологічного niдxодy. Адже його впровадження в навчальний процес $\epsilon$ одним зі шляхів удосконалення та модернізації процесу навчання. Термін «технологія» запозичений із виробничо-технологічної сфери. У «Великому тлумачному словнику української мови» поняття «технологія» пояснюється як «сукупність знань, відомостей про послідовність окремих виробничих операцій у 
процесі виробництва чого-небудь» [1, c. 1295]. Зв'язок цього терміна 3 педагогікою викликав тривалі дискусії. Поступово він сприяв i формуванню особливого, «технологічного» підходу в процесі забезпечення розвитку професійної компетентності майбутніх спортивних менеджерів. Технологічний підхід у професійній діяльності майбутніх фахівців фізичної культури і спорту має сприяти застосуванню таких засобів i методів навчання, щоб під час виконання студентами навчальної і суспільно значимої діяльності у них інтенсивно розвивалися свідомість, теоретичне і практичне мислення. На основі проведених узагальнень можна стверджувати, що технологічний підхід до дослідження проблеми формування професійної компетентності спортивних менеджерів передбачає зміни в організації навчального процесу, його вдосконалення 3 урахуванням сучасного рівня розвитку педагогічних технологій.

У процесі формування професійної компетентності майбутніх менеджерів фізичної культури і спорту помітну роль відіграє методологія застосування інтегративного підходу, спрямованого на якісне вдосконалення наявних методів навчання цих спеціалістів. Такий підхід $\epsilon$ одним 3 визначальних у формуванні їхньої професійної компетентності [9]. Суттю інтеграційного підходу до професійного становлення майбутнього спортивного менеджера $€$ цілісність інтегративно організованого освітнього процесу в єдності його основних напрямів. Визначення цих напрямів інтегративного підходу детерміноване самим процесом ї професійного становлення, який включає мотивацію, діяльність і самопізнання майбутнього фахівця. Інтегративний підхід орієнтує майбутніх спортивних менеджерів на здобуття якісної професійної освіти i досягнення гарантованого результату навчання, націленого на формування особистості майбутнього професіонала через інтеграцію різних видів діяльності в процесі теоретичного і практичного навчання.

Важливою умовою ефективного формування професійної компетентності майбутніх менеджерів фізичної культури i спорту є також застосування акмеологічного nidxoдy, який дає можливість виокремити сукупність тих компетентностей методологічно освіченого майбутнього фахівця, які мають бути новими складниками його образу «Я» як особистості та професіонала. Значну увагу умовам реалізації акмеологічного підходу до розвитку особистості як професіонала приділяе Н. Кузьміна [7]. Учена доводить, що сукупність педагогічних умов для реалізації акмеологічного підходу в професійній освіті має визначатися: суттю самого акмеологічного підходу; змістом акмеологічної спрямованості особистості як мети реалізації акмеологічного підходу; специфікою середовища, організаційними умовами в навчальних закладах, де здійснюється застосування акмеологічного підходу. На нашу думку, реалізація методології акмеологічного підходу значно посилить професійну мотивацію та стимулювання творчого потенціалу майбутнього менеджера фізичної культури i спорту та має знайти відображення в навчальному процесі спортивних вишів.

Методологічні основи формування професійної компетентності майбутніх менеджерів фізичної культури i спорту пов'язані із застосуванням кваліметричного nidxoдy, який містить значні евристичні можливості. Педагогічна кваліметрія, на думку багатьох дослідників, вважається інтегративним поєднанням педагогіки, математики й кібернетики. На думку Е. Яковлєва [10], кваліметричний підхід відкриває значні можливості для реалізації процесу формування професійної компетентності майбутніх спортивних менеджерів. Він базується на концептуальних засадах i методах педагогіки, теорії вимірювання, теорії моделювання й математичної статистики. Використання цього методологічного підходу надає можливість вносити необхідну точність, чіткість у розуміння вихідних даних професійної діяльності, інтерпретацію отриманих результатів, здійснювати прогноз щодо перспектив професійної діяльності майбутніх фахівців фізичної культури i спорту.

Водночас $\mathrm{y}$

комплексі загальнонаукових підходів до формування професійної компетентності майбутніх 
менеджерів фізичної культури і спорту, конкурентоспроможних, здатних професійно організовувати свою діяльність, що відповідає реальним потребам сучасного суспільства, особливої значущості набуває праксеологічний пiдxid. Варто зазначити, що термін «праксеологія» походить від грец. praxis (дія, практика) або латин. praxeus (дія, діяння). Суть праксеології науковці, зокрема Б. Григор'єв і $\quad$ В. Чумакова [2, с. 57], розглядають як «знання про дії», вивчення практики в їі філософському розумінні, тобто отримання найзагальніших відомостей про те, що фахівець має робити у своїй майбутній професійній діяльності. Підкреслюючи необхідність праксеологічної спрямованості формування професійної компетентності майбутніх менеджерів фізичної культури і спорту, потрібно звернути увагу на мету праксеологічного підходу, який визначає найбільш загальні принципи та шляхи підвищення ефективності й корисності їхніх професійних дій, закономірності й умови доцільної та раціональної побудови навчального процесу у вишах, які готують спортивних менеджерів. Таким чином, праксеологічна спрямованість формування професійної компетентності майбутніх спортивних менеджерів передбачає їхню підготовку до об'єктивної самооцінки власних професійних умінь та якостей, виявлених у процесі навчальної практики або в навчальних професійних ситуаціях.

Висновок. Узагальнення методології вищезазначених підходів дає змогу встановити основні вимоги до формування професійної компетентності майбутніх менеджерів фізичної культури і спорту. 3'ясовано, що навчальний процес формування майбутнього спортивного менеджера має бути спрямований на: визначення системної діяльності, розкриття суті механізму іiі реалізації, формування та розвиток у студентів ключових i професійних компетентностей, вибір такого способу організації навчально-пізнавальної діяльності, який би сприяв підготовці професійного, конкурентоспроможного, затребуваного сучасним суспільством спортивного менеджера.

\section{Література}

1. Великий тлумачний словник сучасної української мови / [авт.-уклад. Бусел В. Т.] Київ : Ірпінь : ВТФ «Перун», 2004. - 1440 с.

2. Григорьев Б. В. Праксиология, или Как организовать успешную деятельность: учеб. пособие / Б. В. Григорьев, В. И. Чумакова. - Москва: Школьная пресса, 2002. $-144 \mathrm{c}$.

3. Зимняя И. А. Педагогическая психология / И. А. Зимняя. - Москва : Изд. корпорация Логос, 1999. - 384 с.

4. Ильина А. В. Деятельностный аспект процесса формирования познавательной самостоятельности студентов [Електронний pecypc] / А. В. Ильина. - Режим доступу : www.rusnauka. com/ 8. NPE 2007/ Pedagogica/18478.doc.htm.

5. Колесник І. О. Логіко-гносеологічний підхід у вихованні та принципи його реалізації / I. О. Колесник // Педагогічна освіта: теорія і практика : зб. наук. пр. - 2015. Вип. 18(1-2015). - С. 59-61.
6. Крупник С. А. Методологические подходы к предмету педагогики / С. А. Крупник // Педагогика. - 2000. - № 24. C. 21-26.

7. Кузьмина Н. В. Профессионализм деятельности производственного преподавателя обучения профтехучилища / Н. В. Кузьмина. - Москва : ВНИИ проф.-техн. образования, 1989. - 166 с.

8. Національний освітній глосарій: вища освіта / [авт.-уклад.: І. Бабин, Я. Болюбаш, А. Гармаш та ін. ; за ред. В. Кременя ]. - Київ : Плеяди, 2011. - 100 с.

9. Формування професійної компетентності майбутніх фахівців на основі інтегративного підходу: методичні рекомендації / І. Козловська, Я. Собко, О. Стечкевич, О. Дубницька, Т. Якимович. Львів : Сполом, 2012. - 64 с.

Яковлев Е. В. Квалиметрический подход в педагогическом исследовании: новое видение / Е. В. Яковлев // Педагогика. - 1999. - №3. - C. 49-54. 


\title{
Реферат \\ Формирование профессиональной компетентности будущих спортивных менеджеров: научные подходы
}

\author{
Светлана Крыштанович, \\ кандидат наук государственного управления, \\ доцент кафедры экономики, менеджмента и гостинично-ресторанного бизнеса \\ Львовского государственного университета физической культуры
}

\section{КЛЮЧЕВЫЕ СЛОВА:}

научные подходы, методологические подходы, профессиональная компетентность, спортивный менеджер, высшие учебные заведения, технологии
Проведенный нами анализ научных работ, посвященных формированию профессиональной компетентности будущих менеджеров физической культуры и спорта в условиях динамических изменений на рынке труда, свидетельствует, что эта проблема как в теоретическом, так и в методологическом аспектах, исследована недостаточно. В частности, основательно не проанализированы научные подходы к реализации задач эффективной профессионального подготовка этих специалистов. Своевременность и целесообразность применения методологии в процессе формирования профессиональной компетентности будущих менеджеров физической культуры и спорта обусловлена необходимостью решения определенных противоречий, а именно между: заказом общества на компетентного спортивного менеджера и недостаточными возможностями отечественной образовательной системы в процессе их подготовки; существующей унифицированной системой подготовки будущих специалистов для сферы физической культуры и спорта и необходимостью использования инноваций в учебно-воспитательный процесс высшей школы; осознания студентами необходимости, значимости развития профессиональной компетентности и недостаточным опытом, а также уровнем ее сформированности; необходимостью самосовершенствования и развития профессиональных знаний, умений и навыков преподавателей в условиях бысторотечного образовательного процесса и их неспособностью быстро и оперативно адаптироваться к этим условиям. Поэтому устранения указанных противоречий требует переосмысления концептуальнометодологических подходов к подготовке будущих менеджеров физической культуры и спорта, формирования у них профессиональной компетентности. Система методологических подходов к формированию профессиональной крмпетентности будущих спортивных менеджеров определяет системный, теоретико-познавательный, компетентностный, деятельностный, личностно ориентированный, технологический, интегративный и другие подходы. Нами были рассмотрены содержание и сущность этих подходов. Это позволило установить основные требования к формированию профессиональной компетентности будущих менеджеров физической культуры и спорта и понимание построения учебного процесса в высшей школе, для подготовки данных специалистов. 


\title{
Abstract \\ Formation of Professional Competence of Future Sports Managers. Scientific Approaches
}

\author{
Svitlana Kryshtanovych, \\ PhD in Public Administration, \\ associate professor of the department of economics, \\ management and hotel and restaurant business of \\ Lviv State University of Physical Culture
}

\section{KEY WORDS:}

scientific approaches, methodological approaches, professional competence, sports manager, higher educational establishments, technologies
Our analysis of scientific works is devoted to the formation of professional competence of future physical culture and sports managers in the conditions of dynamic changes in the labor market. It shows that this problem, both in theoretical and methodological aspects, is insufficiently investigated. In particular, scientific approaches to the tasks realization of the specialists effective professional training are not thoroughly analyzed. The timeliness and expediency of the methodology application in the process of the professional competence formation of physical culture and sports future managers is conditioned by the need to resolve certain contradictions, namely: the order of the society to the competent sports manager and the insufficient capacities of the domestic educational system in the process of their training; the existing unified system of future specialists training for the field of physical culture and sports and the need for introduction of innovations into the higher education process; students' awareness of the necessity and significance of the development of professional competence and insufficient experience and level of its formation; the need for self-improvement and development of professional knowledge, skills and abilities of teachers in a rapidly changing educational environment and their inability quick adaptation of to these conditions. Therefore, the elimination of the abovementioned contradictions requires a reconsideration of conceptual and methodological approaches to the training of future physical culture and sports managers, the formation of their professional competence. The system of methodological approaches to the professional competence formation of future sports managers determine systemic, theoretical-cognitive, competence, active, person-oriented, technological, integrative and other approaches. We have considered the content and essence of these approaches. This has allowed to figure out the basic requirements for the professional competence formation of future physical culture and sports managers, and to understand the study organization of the specialists training at higher educational establishments.

\section{References}

1. Velykyi tlumachnyi slovnyk suchasnoi ukrainskoi movy / [avt.-uklad. Busel V. T.] - Kyiv : Irpin: VTF «Perun», 2004. - $1440 \mathrm{~s}$.

2. Grigorieva B. V. Praksiologiia, ili Kak organizovat uspieshnuiu dieiatielnost: uchieb. posobiie / B. V. Grigorieva, V. I. Chumakova. Moskva : Shkolnaia priessa, 2002. - 144 s.

3. Zimniaia I. A. Piedagogichieskaia psikhologiia / I. A. Zimniaia. - Moskva : Izd. Korporaziia Logos, 1999. - $384 \mathrm{~s}$

4. Ilina A.V. Dieiatielnostnyi aspect proziessa formirovaniia poznavatielnoi samostoiatielnosti studientov [Elektronnyi resurs] / A. V. Ilina. Rezhym dostupa: www.rusnauka. com/ 8. NPE 2007/ Pedagogica/18478.doc.htm.

5. Kolesnyk I.O. Lohiko-hnoseolohichnyi pidkhid u vykhovanni ta prynzypy ioho realizatsii / I.O. Kolesnyk // Pedahohichna osvita: teoriia I praktyka : zb. nauk. pr. - Kamianez-Podilsk : KPNU im. I. Ohiienka. - 2015. - S. 28-34.
6. Krupnyk S. A. Mietodologichieskiie podkhody $\mathrm{k}$ priedmietu piedagogiki / S. A. Krupnyk // Piedagogika. - 2000. - №24. - S. 21-26.

7. Kuzmina N. V. Profiessionalizm dieiatielnosti priepodavatielia proizvodstviennogo obuchieniia proftiekhuchilishcha / N. V. Kuzmina. - Moskva : VNII prof.- tiekhn. obrazovaniia, 1989. - $166 \mathrm{~s}$.

8. Nazionalnyi osvitnii hlosarii: vyshcha osvita / [avt.-uklad.: I. Babyn, Ya. Boliubash, A. Harmash ta in. ; za red. V. Kremenia ]. - Kyiv : Pleiady, 2011. $100 \mathrm{~s}$.

9. Formuvannia profesiinoi kompetentnosti maibutnich fakhivziv na osnovi intehratuvnoho pidkhodu: metoduchni rekomendazii / I. Kozlovska, Ya. Sobko, O. Stechkevuch, O. Dubnyzka, T. Yakymovych. - Lviv : Spolom, 2012. - 64 s.

10. Yakovliev Ye. V. Kvaliemietrichieskii podkhod $\mathrm{v}$ piedagogichieskom issliedovanii: novoie vidieniie / Ye. V. Yakovliev // Piedagogika. - 1999. №3. - S. 49-54. 